
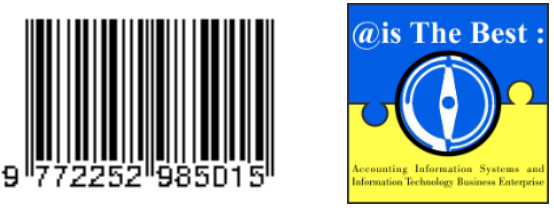

@is The Best :

Accounting Information Systems and

Information Technology Business Enterprise

Volume 02 , Nomor 02

Desember 2017

P-ISSN: 2252-9853

E-ISSN: -

DOI: -

\title{
Perancangan Sistem Informasi Akuntansi Penjualan Yoghurt Pada Koperasi Peternakan Sapi Bandung Utara dengan Menggunakan Microsoft Visual Basic 2005 dan MySQL Berbasis Client Server \\ Ai Suryati ${ }^{1}$, Dony Waluya Firdaus ${ }^{2}$ \\ Jendela Alam Kota Bandung \\ Email: Aiaii chunezz@yahoo.com
}

\section{Keywords:}

Design, Accounting Information System, Microsoft Visual Basic 2005, MySQL annd Client Server

\section{Kata Kunci: \\ Perancangan, Sistem Informasi Akuntansi, Microsoft Visual Basic 2005, MySQL, dan Client Server}

\begin{abstract}
Koperasi Peternak Sapi Bandung Utara (KPSBU) is a cooperative engaged in the business of dairy farmers who process milk into yogurt. Authors conducted a study on the marketing administration in making yogurt sales report still uses Microsoft Excel as a data processing. Based on these problems the authors take the title "Design of Accounting Information Systems Yogurt Sales in North Bandung Cattle Farmer Cooperatives Using Microsoft Visual Basic 2005 and MySQL-Based Client Server 2005"

Design research is a design study with the primary data/secondary, the type of research used academic research, methods of research used field survey techniques and literature, the development model of the system used in the output-oriented methodologies, processes and data. Structures used system development iterations. The design of the information system used context diagrams, data flow diagrams, and flowcharts.
\end{abstract}
Abstrak
Koperasi Peternak Sapi Bandung Utara (KPSBU) merupakan perusahaan yang bergerak di bidang usaha peternakan sapi perah yang mengolah susu sapi menjadi yoghurt. Penulis melakukan penelitian pada bagian administrasi pemasaran dalam pembuatan laporannya masib menggunakan Microsoft Excel sebagai pengolah data. Berdasarkan permasalahan tersebut, penulis mengambil judul "Perancangan Sistem Informasi Akuntansi Penjualan Yoghurt pada Koperasi Peternak Sapi Bandung Utara dengan Menggunakan Microsoft Visual Basic 2005 dan MySQL 2005 Berbasis Client Server".
Desain penelitian yang digunakan adalah penelitian dengan data primer/sekunder, jenis data yang digunakan adalah penelitian akademik, metode yang digunakan adalah dengan teknik survei lapangan dan kepustakaan, model pengembangan sistem yang digunakan metodologi berorientasi pada keluaran, proses, dan data, struktur pengembangan sistem yang digunakan adalah iterasi. Perancangan sistem inormasi yang digunakan diagram konteks, data flow diagram, dan flowchart. 


\section{Pendahuluan}

Saat ini banyak perusahaan yang sudah melakukan pekerjaannya terstruktur menggunakan komputer agar dapat menghemat waktu dan biaya serta dapat menghasilkan sebuah informasi yang lebih akurat bagi perusahaan terutama informasi keuangan yang dibutuhkan sesuai dengan Standar Akuntansi. Suatu perusahaan membutuhkan suatu sistem yang dapat menghasilkan sebuah informasi keuangan pada bagian pemasaran yaitu mengenai sistem informasi penjualan.

Koperasi Peternak Sapi Bandung Utara (KPSBU) Jawa Barat bergerak dibidang usaha peternak susu perah yang kemudian susu tersebut dijadikan sebagai youghurt frestime. Dalam melakukan pencatatan dan pembuatan laporan penjualannya sudah terkomputerisasi menggunakan Microsoft Excel namun belum sesuai dengan Standar Akuntansi Keuangan (SAK) sehingga akan mengakibatkan kesalahan-kesalahan yang mungkin terjadi dalam memasukan datanya.

Berdasarkan uraian di atas, penulis bermaksud untuk menanggulagi permasalahan yang terjadi, dan melakukan penelitian dengan judul "Perancangan Sistem Informasi Akuntansi Penjualan Yoghurt Pada Koperasi Peternak Sapi Bandung Utara Dengan Menggunakan Software Microsoft Visual Basic 2005 dan MySQL Berbasis Client Server"

\section{Identifikasi Masalah}

Penulis mengidentifikasi masalah masalah yang sesuai dengan Sistem Informasi Penjualan Yoghurt sebagai berikut.

A. Bagainana pencatatan penjualan Yoghurt dan struktur organisasi yang berjalan pada Koperasi Peternak Sapi Bandung Utara (KSPBU).

B. Bagaimana Perancangan Sistem Informasi Akuntansi Penjualan Yoghurt Pada Koperasi Peternak Sapi Bandung Utara Dengan Menggunakan Software Microsoft Visual Basic 2005 dan MySQL Berbasis Client Server.

\section{Batasan Masalah} Yoghurt:

Berikut adalah batasan masalah dalam perancangan Sistem Informasi Akuntansi Penjualan

A. Penulis melakukan penelitian pada Koperasi Peternak Susu Bandung Utara mengenai pencatatan penjualan Yoghurt.

B. Perancangan Sistem Informasi Akuntansi Penjualan Yoghurt Pada Koperasi Peternak Sapi Bandung Utara Dengan Menggunakan Software Microsoft Visual Basic 2005 dan MySQL Berbasis Client Server

\section{Tujuan Penelitian}

Berikut adalah tujuan dilaksanakan penelitian mengenai Sistem Informasi Akuntansi Penjualan Yoghurt:

A. Untuk mengetahui pencatatan penjualan yoghurt pada KPSBU

B. Untuk merancang Sistem Informasi Akuntansi Penjualan Yoghurt Pada Koperasi Peternak Sapi Bandung Utara Dengan Menggunakan Software Microsoft Visual Basic 2005 dan MySQL Berbasis Client Server. 

Yoghurt pada Koperasi Peternak Sapi Bandung Utara dengan Menggunakan Microsoft Visual

Basic 2005 dan MySQL 2005 Berbasis Client Server

\section{Kerangka Teoritis dan Pengembangan Hipotesis}

\section{Perancangan}

Perancangan dalam buku yang berjudul Sistem Informasi Akuntansi dijelaskan sebagai berikut:

"Perancangan adalah terdiri dari perancangan logis yaitu melengkapi eksternal level schema dan menterjemahkan persyaratan data para pemakai dan program aplikasi kedalam conceptual level schema sedangkan perancangan fisik adalah penyimpanan hasil rancangan konsep kedalam struktur penyimpanan fisik" [1].

Berdasarkan uraian di atas, penulis menyimpulkan bahwa perancangan ialah tahapan atau rancangan dalam pembuatan suatu sistem yang dibuat dari satu elemen ke elemen lainnya.

\section{Sistem}

Definisi Sistem dalam buku yang berjudul Sistem Akuntansi menjelaskan bahwa "sistem merupakan sekelompok unsur yang erat berhubungan satu dengan yang lainnya, yang berfungsi bersama-sama untuk mencapai tujuan tertentu" [2].

Definisi lain sistem menurut dalam bukunya yang berjudul Sistem Informasi Akuntansi, menyebutkan: "Sistem adalah kumpulan/group dari sub sistem/bagian/komponen apapun baik phisik yang saling berhubungan satu sama lain dan bekerja sama secara harmonis untuk mencapai satu tujuan"'[3].

Berdasarkan uraian di atas, sistem merupakan kumpulan komponen yang saling berhubungan satu sama lain sehingga dapat mencapai suatu tujuan bersama.

\section{Informasi}

Definisi Informasi dalam buku Sistem Informasi Akuntansi menjelaskan bahwa "informasi adalah pengolahan data yang memberikan arti dan manfaat"'[3]. Definisi lain dari informasi dalam buku Sistem Informasi Akuntansi menjelaskan bahwa informasi adalah data yang telah diorganisasi, dan telah memiliki kegunaan dan manfaat[4].

Definisi informasi dalam buku yang berjudul Analisis dan Design, menjelaskan bahwa: "informasi adalah data yang diolah menjadi bentuk yang lebih berguna dan lebih berarti bagi yang menerimanya" [5].

Berdasarkan uraian di atas, informasi merupakan data yang telah diolah menjadi sesuatu yang bermanfaat bagi penerimanya. 
Utara dengan Menggunakan Microsoft Visual

Basic 2005 dan MySQL 2005 Berbasis Client Server

\section{Akuntansi}

Definisi akuntansi yang berjudul Akuntansi Koperasi adalah sebagai berikut:“akuntansi adalah Sistem informasi yang menghasilkan laporan kepada pihak-pihak yang berkepentingan mengenai aktivitas ekonomi dan kondisi suatu badan usaha" [6] .

Definisi akuntansi dalam dalam bukunya yang berjudul Akuntansi Koperasi pengertian akuntansi adalah sebagai berikut: “Akuntansi adalah aktivitas mengumpulkan, menganalisis, menyajikan dalam bentuk angka, mengklasifikasikan, mencatat, meringkas, dan melaporkan aktivitas/transaksi suatu badan usaha dalam bentuk informasi keuangan" [6].

\section{Sistem Informasi Akuntansi}

Sistem informasi akuntansi dalam buku yang berjudul Sistem Informasi Akuntansi dijelaskan bahwa: "Sistem informasi akuntansi adalah sebuah sistem yang memproses data dan transaksi guna menghasilkan informasi yang bermanfaat untuk merencanakan, mengendalikan dan memproses bisnis" [1].

Denisi lain dari sistem informasi akuntasi dalam buku yang berjudul Analisis dan Desain Sistem Informasi, adalah sebagai berikut:

"Sistem informasi akuntansi adalah kumpulan kegiatan-kegiatan dari organisasi yang bertanggungjawab untuk menyediakan informasi keuangan dan informasi yang didapatkan dari transaksi data untuk tujuan pelaporan internal kepada manajer untuk digunakan dalam pengendalian dan perencanaan sekarang dan operasi masa depan serta pelaporan eksternal kepada pemegang saham. Pemerintah dan pihak-pihak luar lainnya"[7].

Berdasarkan pengertian di atas maka penulis dapat menyimpulkan bahwa sistem informasi akuntansi merupakan suatu proses pengolahan data yang hasil akhir menghasilkan sebuah informasi laporan keuangan yang telah terkomputerisasi.

\section{Perhitungan Hasil Usaha}

Dalam buku Akuntansi Koperasi, definisi perhitungan hasil usaha adalah sebagai berikut: 
"Suatu laporan yang menunjukan kemampuan koperasi dalam menghasilkan laba selama suatu periode akuntansi atau satau tahun. Laporan hasil usaha harus merinci hasil usaha yang berasal dari anggota dan laba yang diperoleh dari aktivitas koperasi dengan bukan anggota" [6]

\section{Penjualan}

Dalam buku yang berjudul Akuntansi Suatu Pengantar, penjualan dijelaskan sebagai berikut: "penjualan adalah penjualan barang dagang oleh perusahaan, penjualan dapat dilakukan secara kredit atau tunai" [8]

Berdasarkan uraian di atas, penjualan dapat disimpulkan sebagai suatu transaksi menjual barang dagang yang dapat dilakukan secara kredit maupun tunai.

\section{Sistem Informasi Akuntansi Penjualan}

Sistem informasi akuntansi penjualan merupakan sebuah rancangan atau susunan dari beberapa komponen atau unit yang saling berhubungan satu sama lain yang dapat menghasilkan suatu laporan bagi perusahaan mengenai transaksi kegiatan penjualan perusahaan baik secara kredit maupu tunai.

\section{Perancangan Sistem Informasi Akuntansi Penjualan}

Perancangan sistem informasi akuntansi penjualan merupakan sebuah rancangan sistem atau susunan dari beberapa komponen atau unit yang saling berhubungan satu sama lain yang dapat menghasilkan suatu informasi transaksi kegiatan penjualan perusahaan baik secara kredit maupu tunai.

\section{Metode}

\section{Unit Analisis}

Dalam buku yang berjudul Metode Penelitian untuk Akuntansi, unit analisis dinyatakan bahwa "unit analisis merupakan satuan terkecil dari objek penelitian yang diinginkan oleh peneliti sebagai klasifikasi pengumpulan data" [9].

Sedangkan dalam buku yang berjudul Metedologi Penelitian untuk Bisnis unit analisis dijelaskan bahwa "unit analisis adalah tingkat pengumpulan data yang dikumpulkan selama analisa data" [10] 
Unit analisi yang diteliti yaitu pada KPSBU (Koperasi Peternak Sapi Bandung Utara) di Kompleks Pasar Panorama Lembang Bandung tepatnya pada bagian administrasi mengenai penjualan.

\section{Populasi}

Definisi populasi berdasarkan buku Metode Penelitian bahwa: "populasi adalah kumpulan dari individu dengan kualitas serta ciri-ciri yang telah ditetapkan. Sampel adalah bagian dari populasi”. [11]

Sedangkan dalam buku yang berjudul Analisis dan Desain Sistem Informasi dijelaskan bahwa: "populasi adalah seluruh item yang ada." [7]. Berdasarkan populasi yang penulis teliti yaitu bagian laporan penjualan tahun 2012.

Berdasarkan kedua definisi tersebut, maka Peneliti dapat menyimpulkan bahwa populasi merupakan semua atau seluruh kesatuan elemen-elemen yang diteliti oleh peneliti yang ada pada suatu wilayah atau tempat. Populasi yang Peneliti teliti yaitu Koperasi Peternak Sapi Bandung Utara.

\section{Objek Penelitian}

Objek penelitian yang dilakukan adalah menguraikan penjelasan mengenai sistem informasi akuntansi penjualan serta merancang sebuah sistem informasi akuntansi penjualan dengan menggunakan software Microsoft visual basic 2005 dan MySQL berbasis client server.

\section{Desain Penelitian}

Desain penelitian berdasarkan buku Metode Penelitian dijelaskan bahwa: "desain dari penelitian adalah semua proses yang diperlukan dalam perencanaan dan pelaksanaan penelitian" [11].

Penulis menggunakan metode penelitian data primer dan data sekunder, dalam buku Metode Penelitian dijelaskan bahwa:

"Desain penelitian data primer dan data sekunder adalah desain pengumpulan data yang efisien dengan alat dan teknik serta karakteristik dari responden. Jika peneliti ingin menggunakan data sekunder, maka si peneliti harus mengadakan evaluasi terhadap sumber, keadaan data sekundernya dan juga si peneliti harus menerima limitasi-limitasi dari data tersebut" [11]. 
Berdasarkan uraian di atas, data primer merupakan data yang diambil dari orang pertama dan tidak mengalami perubahan, sedangkan data sekunder diambil dari orang ketiga atau yang telah dimodifikasi.

\section{Metode Penelitian}

Langkah-langkah dalam penelitian atau yang disebut dengan metode penelitian yang digunakan penulis adalah metode penelitian deskriptif dan survei, dalam buku yang berjudul Metode Penelitian dijelaskan bahwa: "Metode Penelitian deskriptif yaitu suatu metode dalam meneliti status kelompok manusia, suatu objek, suatu set kondisi, suatu sistem pemikiran ataupun suatu kelas peristiwa pada masa sekarang" [11].

Sedangkan survei dijelaskan sebagai berikut: "Metode Survei adalah penyelidikan yang diadakan untuk memperoleh fakta-fakta dari gejala-gejala yang ada dan mencari keteranganketerangan secara faktual, baik tentang institusi sosial, ekonomi, atau politik dari suatu kelompok ataupun suatu daerah" [11].

\section{Metodologi Pengembangan Sistem}

Metodologi pengembangan sistem dalam buku Analisis dan Desain Sistem Informasi dijelaskan sebagai berikut: "Metodologi pengembangan sistem adalah metode-metode, prosedurprosedur, konsep-konsep pekerjaan, aturan-aturan dan dan postulat-postulat yang akan digunakan untuk mengembangkan suatu sistem informasi" [7].

Sedangkan dalam buku Analisis Sistem Informasi bahwa: "metodologi pengembangan sistem adalah metode-metode, prosedur-prosedur, konsep-konsep pekerjaan dan aturan-aturan untuk mengembangkan suatu sistem informasi” [12].

Penulis menyimpulkan bahwa metodologi pengembangan sistem merupakan suatu cara yang dilakukan oleh peneliti untuk pengembangan suatu sistem yang telah ada.

\section{Model Pengembangan Sistem}

Dalam buku yang berjudul Analisis Sistem Informasi, model pengembangan sistem dijelaskan bahwa: "Model pengembangan sistem adalah tahapan-tahapan tersebut dilaksanakan dengan pemakai teknik iterasi atau dimana suatu proses dilaksanakan secara berulang-ulang sampai didapatkan hasil yang diinginkan" [12]

Berikut adalah model pengembangan sistem menurut Tata Sutabri: 
Nama penulis : Ai Suryati, Dony Waluya Firdaus

Judul : Perancangan Sistem Informasi Akuntansi Penjualan Yoghurt pada Koperasi Peternak Sapi Bandung

Utara dengan Menggunakan Microsoft Visual Basic 2005 dan MySQL 2005 Berbasis Client Server
Jurnal @ is The Best Vol. 02 No. 02. Desember 2017: Hal 131-148

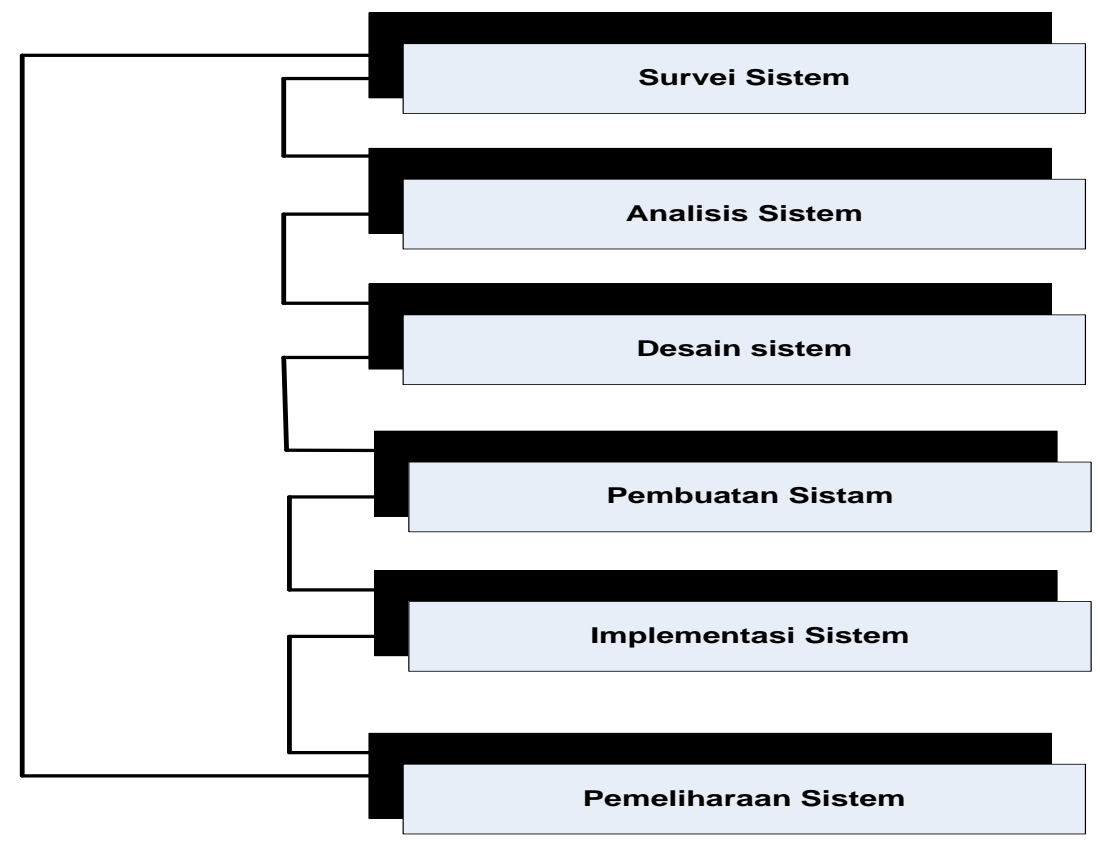

Gambar 1 Model Sistem Iterasi[12]

\section{Lokasi Penelitian}

Penulis melakukan penelitian pada Koperasi Peternak Sapi Bandung Utara (KPSBU) yang berlokasi di Komplek Pasar Panorama Lembang Bandung Telp. 022-2786198 Fax 022-2786431 Website: www.kpsbu.ac.id. 
Nama penulis : Ai Suryati, Dony Waluya Firdaus

Judul : Perancangan Sistem Informasi Akuntansi Penjualan Yoghurt pada Koperasi Peternak Sapi Bandung

Utara dengan Menggunakan Microsoft Visual

Basic 2005 dan MySQL 2005 Berbasis Client Server
Jurnal @ is The Best Vol. 02 No. 02. Desember 2017: Hal 131-148

\section{Hasil dan Pembahasan}

\section{Struktur Organisasi Berjalan}

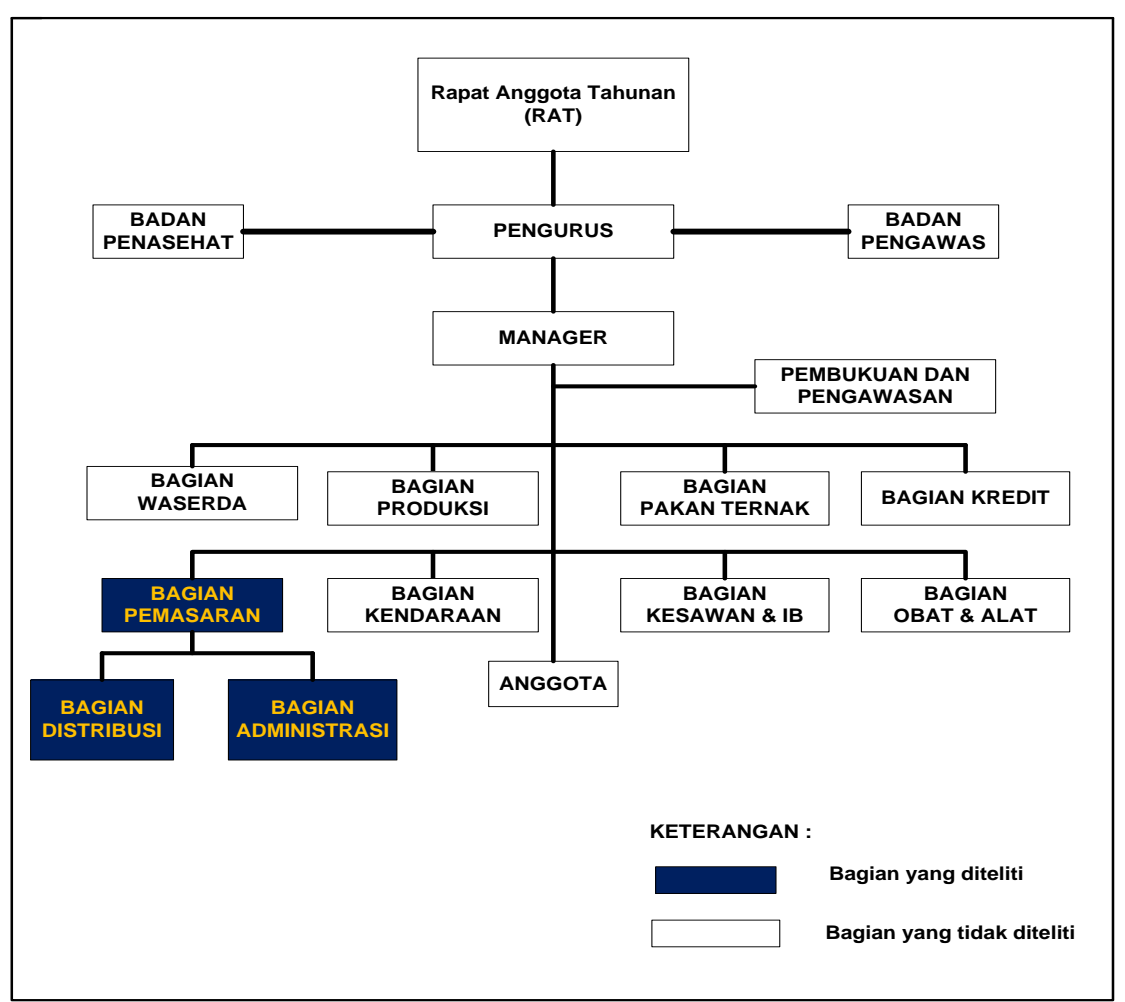

Gambar 2 Struktur Organisasi Berjalan

\section{Data Flow Diagram}

\section{a. Diagram Konteks Berjalan}


Nama penulis : Ai Suryati, Dony Waluya Firdaus

Judul : Perancangan Sistem Informasi Akuntansi Penjualan Yoghurt pada Koperasi Peternak Sapi Bandung

Utara dengan Menggunakan Microsoft Visual

Basic 2005 dan MySQL 2005 Berbasis Client Server
Jurnal @ is The Best Vol. 02 No. 02. Desember 2017: Hal 131-148

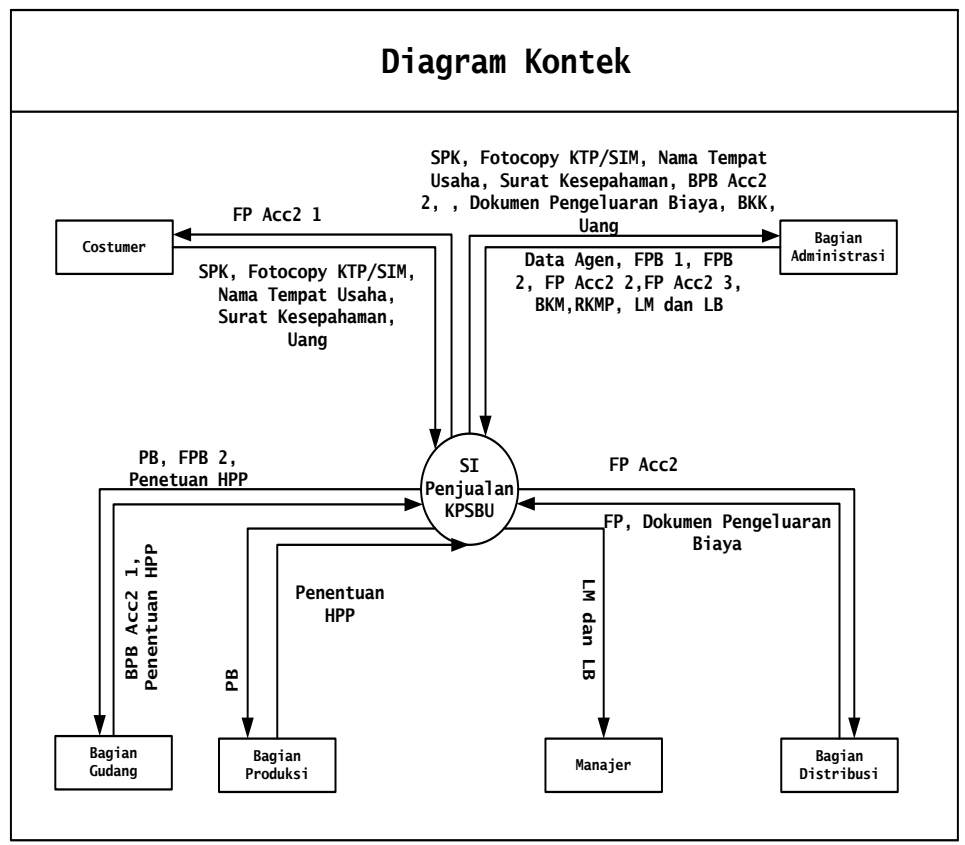

Gambar 3 Diagram Konteks Berjalan

b. Data Flow Diagram (Diagram Alur Data) Level 0 Yang Berjalan

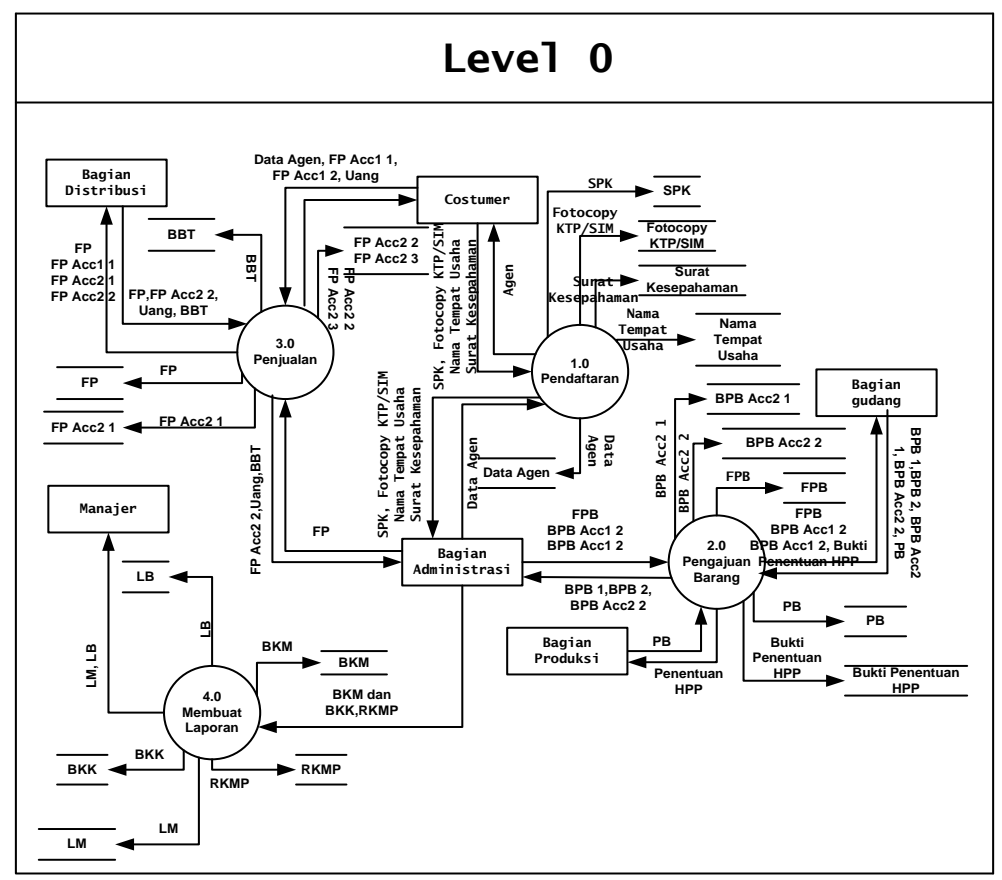

Gambar 4 Data Flow Diagram Level 0 Berjalan

\section{Bagan Alir Dokumen Berjalan}


Nama penulis : Ai Suryati, Dony Waluya Firdaus

Judul : Perancangan Sistem Informasi Akuntansi Penjualan Yoghurt pada Koperasi Peternak Sapi Bandung

Utara dengan Menggunakan Microsoft Visual

Basic 2005 dan MySQL 2005 Berbasis Client Server
Jurnal @ is The Best Vol. 02 No. 02. Desember 2017: Hal 131-148

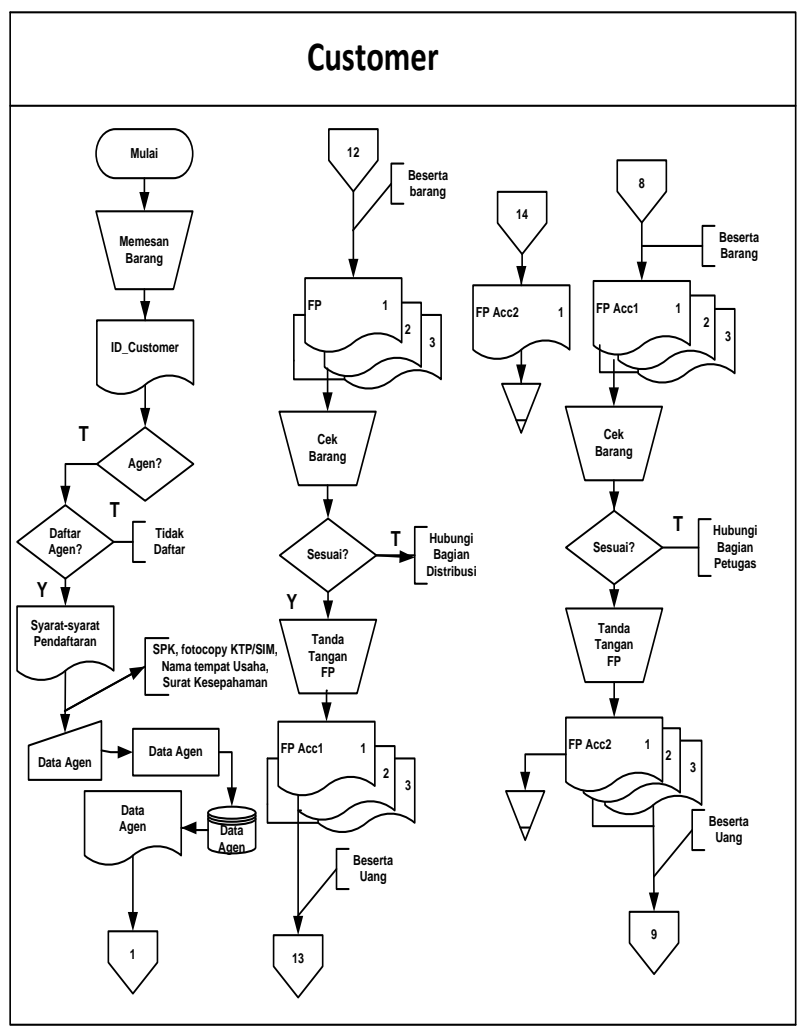

Gambar 5 Bagan Alir Dokumen Berjalan

\section{Pembahasan}

\section{Data Flow Diagram yang Diusulkan}

\section{Diagram Konteks}

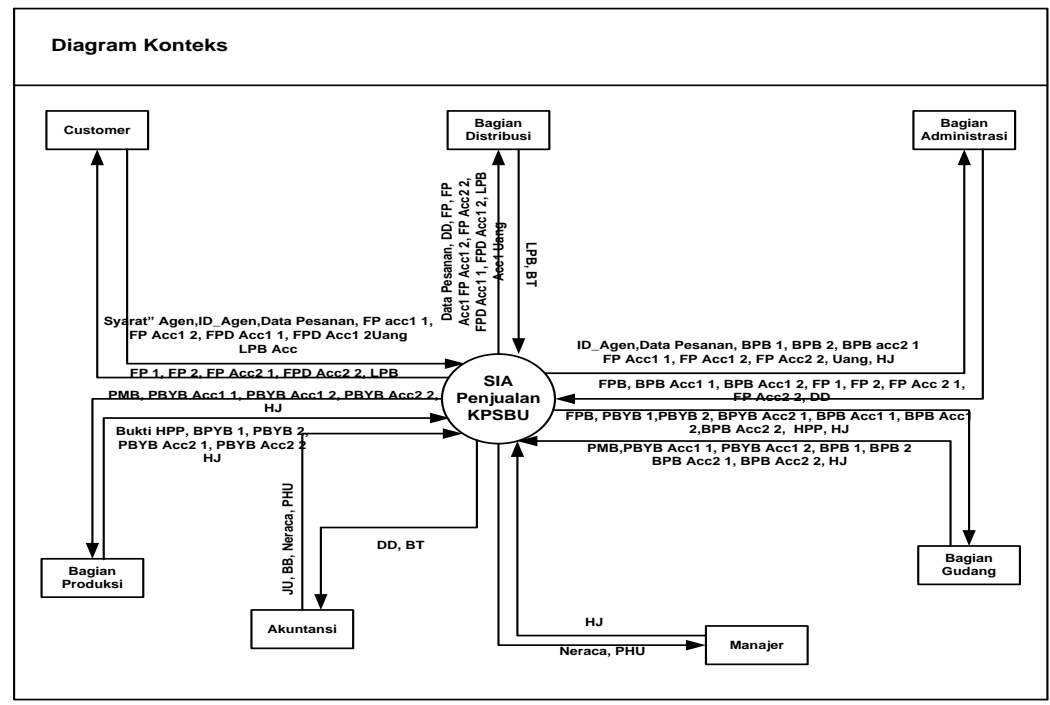

Gambar 6 Diagram Konteks yang Diusulkan

\section{Diagram Level 0 yang Diusulkan}


Nama penulis : Ai Suryati, Dony Waluya Firdaus

Judul : Perancangan Sistem Informasi Akuntansi Penjualan Yoghurt pada Koperasi Peternak Sapi Bandung

Utara dengan Menggunakan Microsoft Visual

Basic 2005 dan MySQL 2005 Berbasis Client Server
Jurnal @ is The Best Vol. 02 No. 02. Desember 2017: Hal 131-148

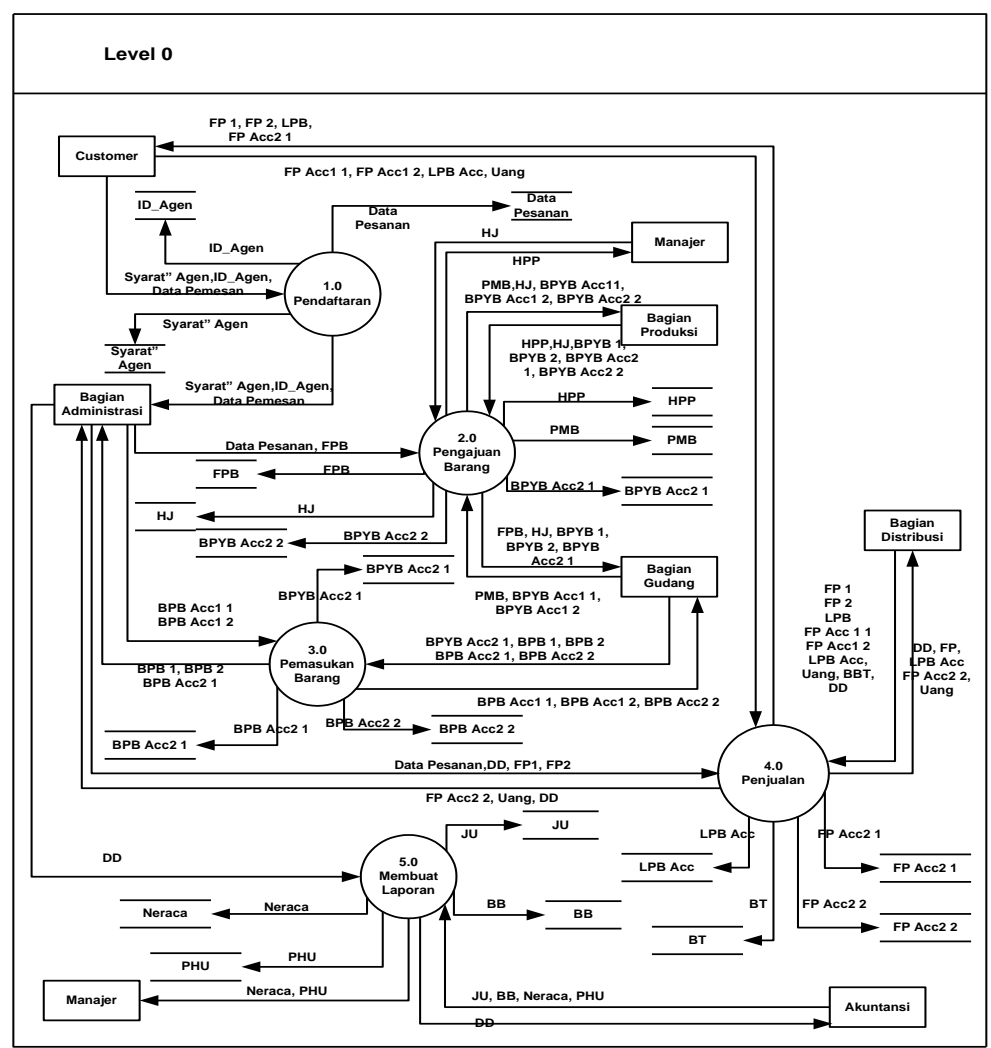

Gambar 7 Data Flow Diagram Level 0 Sistem yang Diusulkan

\section{Bagan Alir Sistem Usulan}


Nama penulis : Ai Suryati, Dony Waluya Firdaus

Judul : Perancangan Sistem Informasi Akuntansi Penjualan

Yoghurt pada Koperasi Peternak Sapi Bandung

Utara dengan Menggunakan Microsoft Visual

Basic 2005 dan MySQL 2005 Berbasis Client Server
Jurnal @ is The Best Vol. 02 No. 02. Desember 2017: Hal 131-148

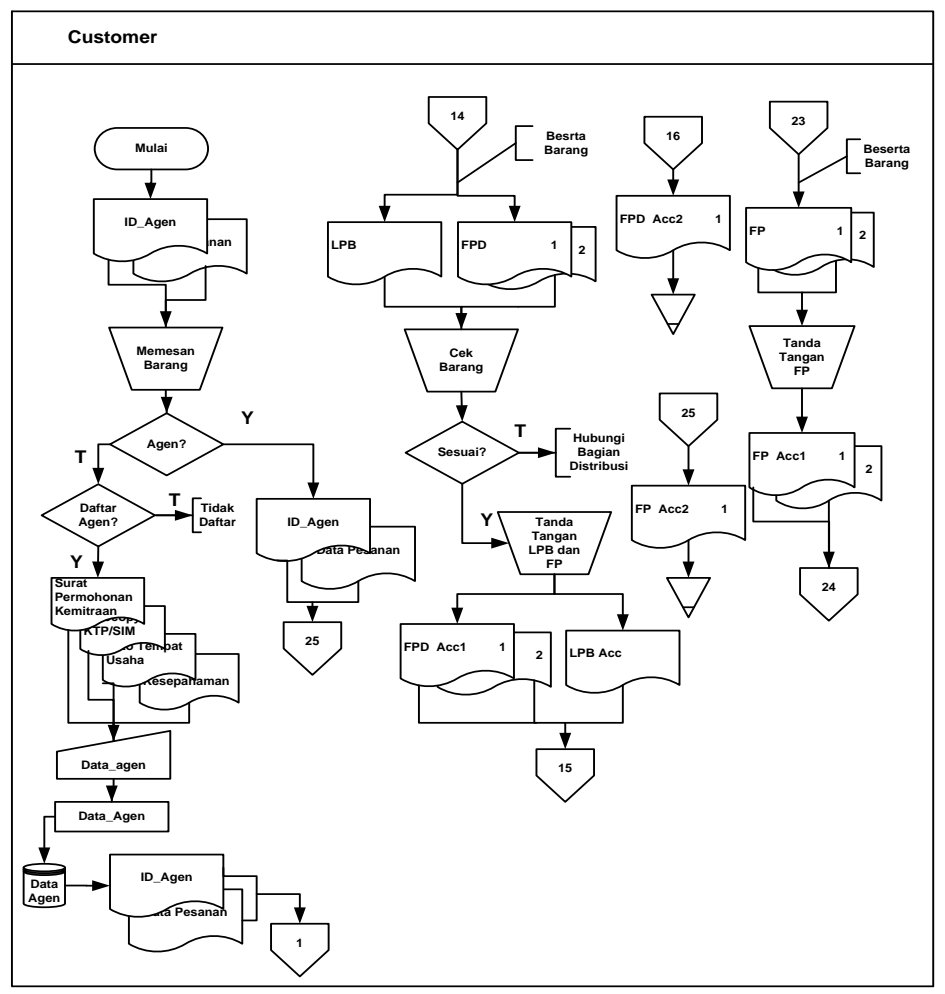

Gambar 8 Bagan Alir Sistem Usulan

\section{ERD Usulan}

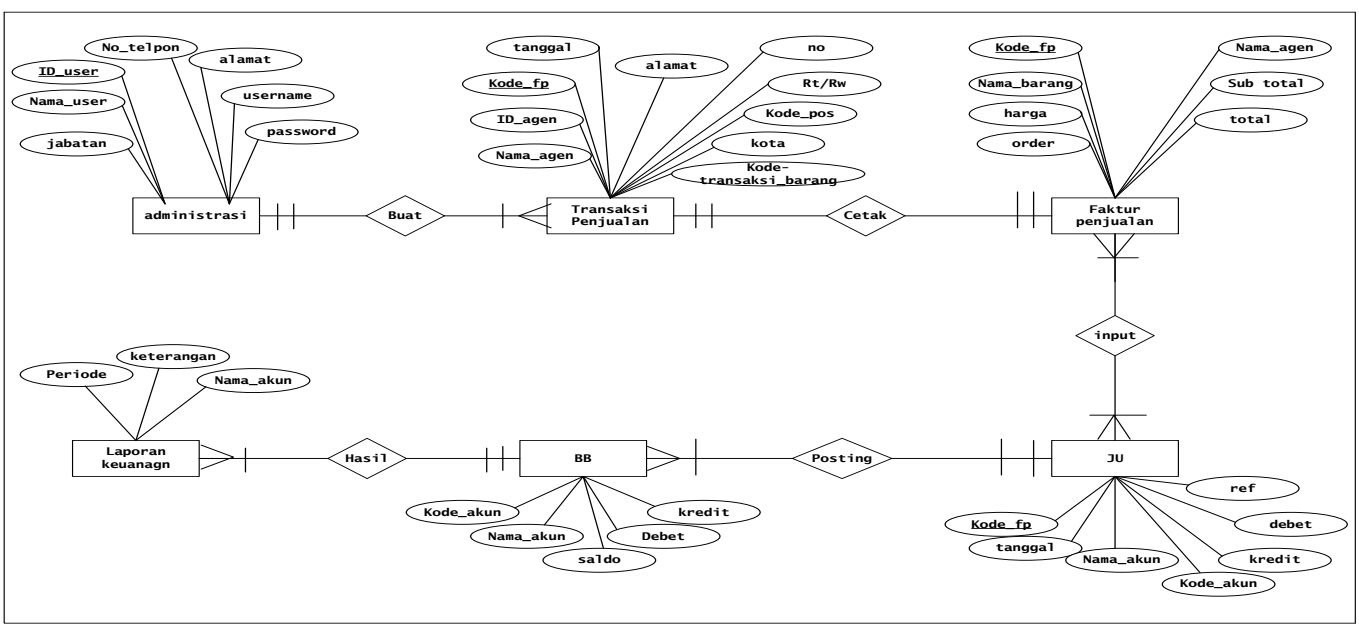

Gambar 10 ERD Usulan 
Nama penulis : Ai Suryati, Dony Waluya Firdaus

Judul : Perancangan Sistem Informasi Akuntansi Penjualan Yoghurt pada Koperasi Peternak Sapi Bandung

Utara dengan Menggunakan Microsoft Visual

Basic 2005 dan MySQL 2005 Berbasis Client Server

\section{Perancangan Menu Program}

a. Account dan Code Account yang Diusulkan

\begin{tabular}{|l|l|}
\hline Kode Akun & Nama Akun/Rekening \\
\hline 1.1 .1 & Kas \\
4.1 .1 & Penjualan \\
5.1 .0 & Beban Transportasi \\
\hline
\end{tabular}

Gambar 11 Account dan Code Account yang Diusulkan

\section{b. Struktur Menu Program}

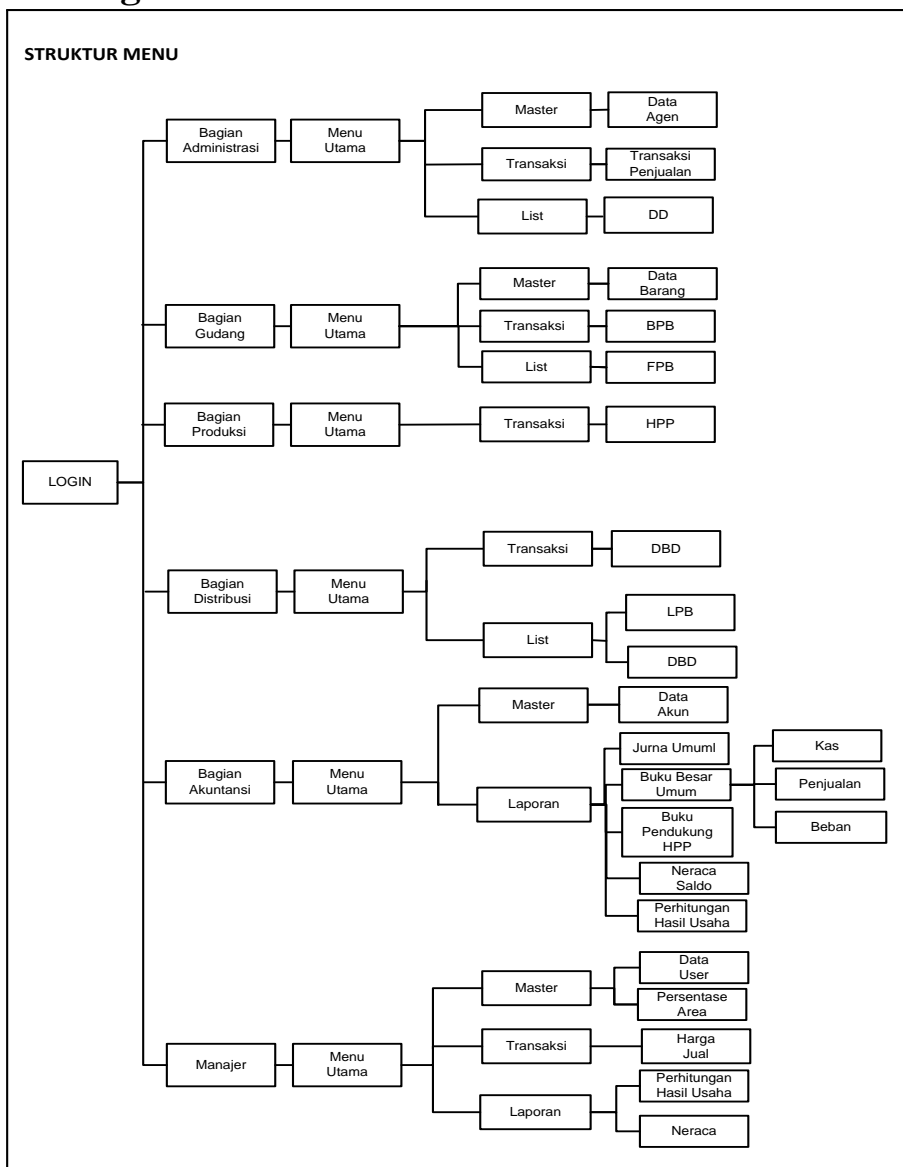

Gambar 12 Struktur Menu Program Usulan 
Nama penulis : Ai Suryati, Dony Waluya Firdaus

Judul : Perancangan Sistem Informasi Akuntansi Penjualan Yoghurt pada Koperasi Peternak Sapi Bandung

Utara dengan Menggunakan Microsoft Visual

Basic 2005 dan MySQL 2005 Berbasis Client Server
Jurnal @ is The Best Vol. 02 No. 02. Desember 2017: Hal 131-148

\section{c. Tampilan}

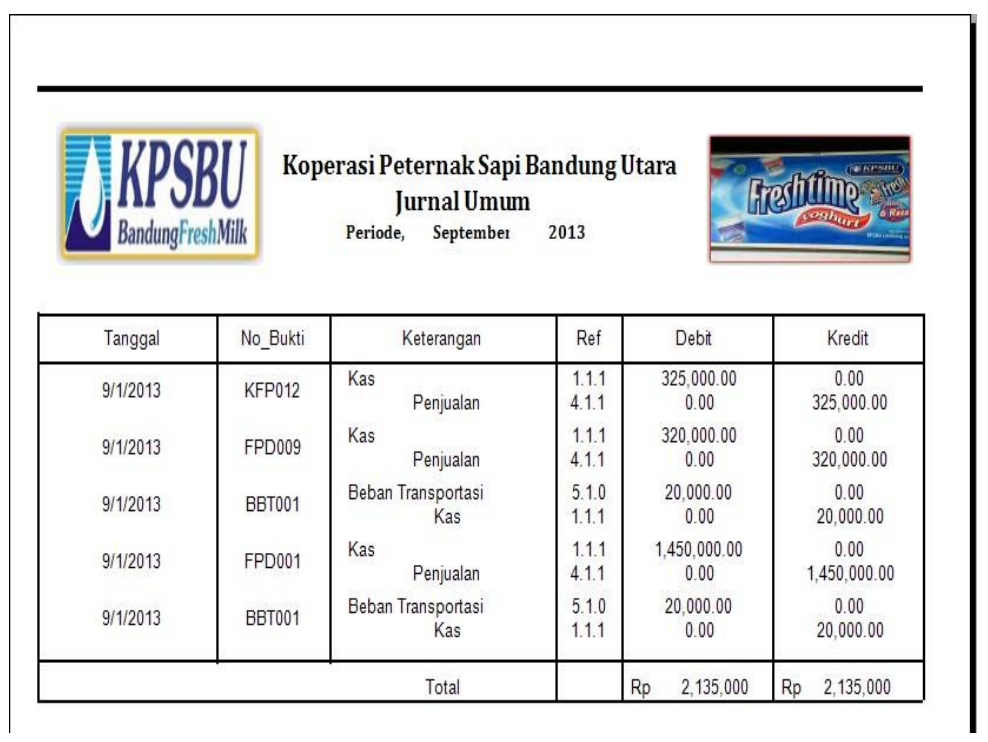

Gambar 13 Tampilan Cetak Jurnal Umum

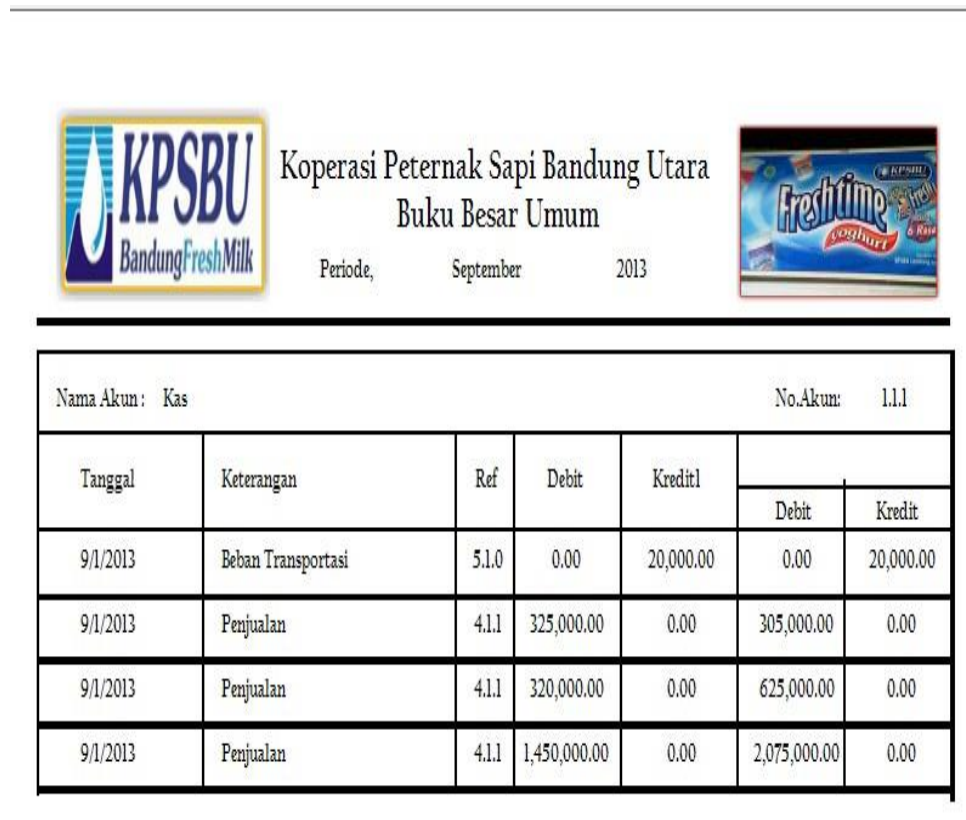

Gambar 14 Tampilan Cetak Buku Besar Umum Kas 
Nama penulis : Ai Suryati, Dony Waluya Firdaus

Judul : Perancangan Sistem Informasi Akuntansi Penjualan Yoghurt pada Koperasi Peternak Sapi Bandung

Utara dengan Menggunakan Microsoft Visual

Basic 2005 dan MySQL 2005 Berbasis Client Server
Jurnal @ is The Best Vol. 02 No. 02. Desember 2017: Hal 131-148

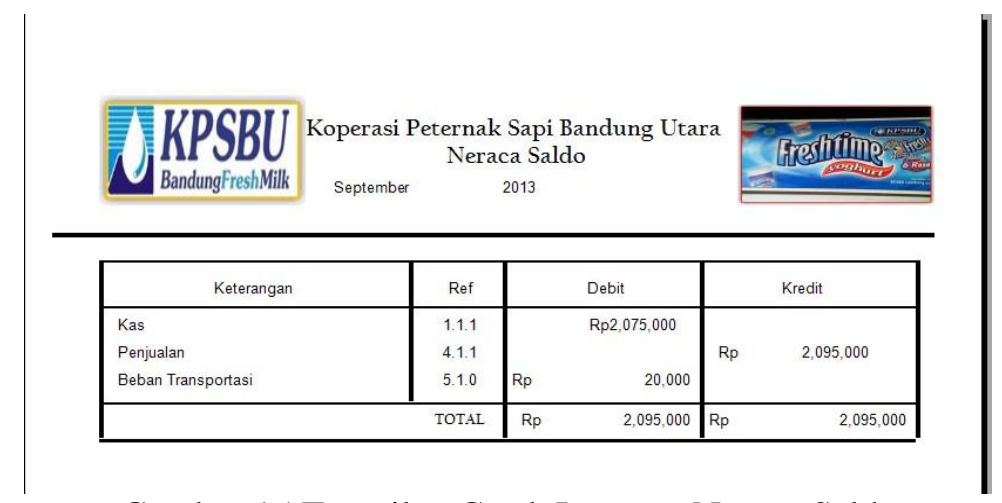

Gambar 15 Tampilan Cetak Laporan Neraca Saldo

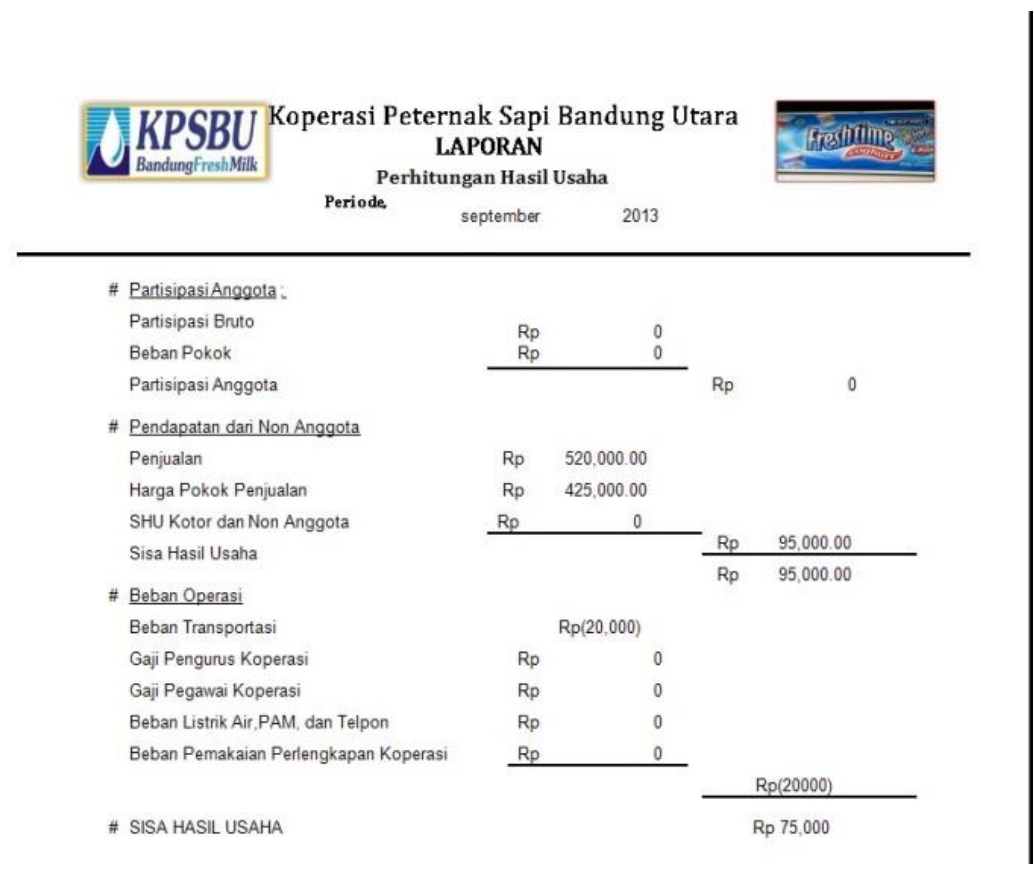

Gambar 16 Tampilan Perhitungan Hasil Usaha 


\section{Penutup}

\section{Simpulan}

Berdasarkan hasil penelitian pada KPSBU (Koperasi Peternak Sapi Bandung Utara) tepatnya dibagian administrasi, maka penulis dapat menyimpulkan sebagai berikut:

A. KPSBU (Koperasi Peternak Sapi Bandung Utara) merupakan suatu koperasi dimana koperasi ini bergerak dibidang usaha peternak sapi perah dimana susu perahannya tersebut diproduksi dan dijual menjadi sebuah yoghurt. Namun dalam pencatatan laporan penjualan masih menggunakan MS. Excel sehingga membutuhkan banyak waktu dalam proses pencatatan laporan.

B. Perancangan yang dibuat ini terdapat beberapa sistem diantaranya terdiri dari sistem diagram konteks, Data flow diagram, entity relationship diagram, dan flowchart, yang berupa inputan dari data-data transaksi penjualan yoghurt berhubungan dengan laporan keuangan perhitungan hasil usaha dan dengan menggunakan Visual Basic 2005 dan MySQL sehingga dapat memudahkan dalam proses pengolahan data laporan keuangan yang sesuai dengan standar akuntansi keuangan dan proses yang dilakukan tidak banyak memakan waktu yang lama.

\section{Saran}

Hasil tinjauan dan analisis penulis selama meneliti yaitu:

A. Diperlukan ketelitian pada saat pemasukan data agar data yang dihasilkan sesuai dengan yang diharapkan.

B. Proses alur yang dibuat perlu di manajemn kembali agar lebih jelas dalam proses penjualan Delivery. 
Nama penulis : Ai Suryati, Dony Waluya Firdaus

Judul : Perancangan Sistem Informasi Akuntansi Penjualan Yoghurt pada Koperasi Peternak Sapi Bandung Utara dengan Menggunakan Microsoft Visual Basic 2005 dan MySQL 2005 Berbasis Client Server
Jurnal @ is The Best Vol. 02 No. 02. Desember 2017: Hal 131-148

\section{Daftar Pustaka}

[1] Krismiaji, Sistem Informasi Akuntansi. Yogyakarta: Penerbit Unit Penerbit dan Percetakan AMP YKPN, 2005.

[2] Mulyadi, Sistem Akuntansi. Jakarta: Salemba Empat, 2008.

[3] A. Susanto, Sistem Informasi Akuntansi. Bandung: Lingga Jaya, 2013.

[4] Krismiaji, Sistem Informasi Akuntansi. Yogyakarta: AMP YKPN, 2010.

[5] Hartono, Analisis dan Desain Sistem Informasi. Jakarta: Ghalia Indonesia, 2005.

[6] Rudianto, Akuntansi Koperasi, Edisi 2. Jakarta: Erlangga, 2010.

[7] H. . Jogiyanto, Analisis dan Desain Sistem Informasi. Yogyakarta: Andi Offset, 2005.

[8] Soemarso, Akuntansi Suatu Pengantar. Jakarta: Salemba Empat, 2009.

[9] S. Efferin, Metode Penelitian untuk Akuntansi. Jawa Timur: Bayumedia Publising, 2004.

[10] U. Sekaran, Metodologi Penelitian untuk Bisnis. Jakarta: Salemba Empat, 2006.

[11] M. Nazir, Metode Penelitian. Jakarta: Ghalia Indonesia, 2005.

[12] T. Sutarbi, Analisa Sistem Informasi. Yogyakarta: Andi Offset, 2004. 